\title{
Pathophysiological analysis of hypoxaemia during acute severe asthma
}

\author{
T HORI
}

Department of Paediatrics, Osaka City University, Japan

SUMMARY Blood gas measurements obtained during 35 episodes of acute, severe asthma in 19 children were analysed. Arterial carbon dioxide tension $\left(\mathrm{PaCO}_{2}\right)$ was mean (SD) $5 \cdot 7(1.2) \mathrm{kPa}$ and the arterial oxygen tension $\left(\mathrm{PaO}_{2}\right)$ was $7 \cdot 7(1 \cdot 1) \mathrm{kPa}$. Hypoxaemia was severe $\left(\mathrm{PaO}_{2} \leqslant 7 \cdot 9 \mathrm{kPa}\right)$ on 19 occasions, was present alone (type I) on eight of these, and was associated with hypercapnia (type II) on 11. The $\mathrm{PaO}_{2}$ was similar in both the type I and type II subgroups, but $\mathrm{PaCO}_{2}$ was significantly higher in the type II and the alveolar-arterial oxygen tension difference was significantly higher in the type I subgroup. Classification of acute respiratory failure into these two types proved useful in understanding the pathophysiology of acute, severe asthma. Type I failure, conventionally regarded as a precursor of type II, itself caused severe, critical hypoxaemia.

Acute severe asthma is a medical emergency, and the importance of blood gas measurement has been widely recognised. ${ }^{12}$ So far, however, knowledge of blood gas disorders during acute, severe asthma has been almost exclusively obtained from experience in adults, ${ }^{34}$ and reports on children have been limited. ${ }^{5-7}$

Recently, the pathophysiological classification of acute respiratory failure into hypoxaemic respiratory failure (type I) and hypoventilatory failure (type II) has been postulated, ${ }^{89}$ but the clinical and theoretical usefulness of this classification in children with acute, severe asthma has never been discussed fully. We examined blood gas disorders in asthmatic children in terms of the arterial oxygen and carbon dioxide tensions and the alveolar-air equation, and discuss two physiological causes of profound hypoxia in acute severe asthma-alveolar hypoventilation and ventilation perfusion inequality (V/Q mismatch). ${ }^{10}$

\section{Patients and methods}

Thirty five acute asthmatic attacks in 19 children ( 9 boys and 10 girls) aged from 4 to 19 years (mean (SD), $11.4(3.2)$ years) were analysed. On every occasion, orthopnoea, weakness of respiratory sounds, and speech disturbance were seen, and the clinical score of McKenzie ${ }^{7}$ was always above six/nine. On 30 occasions, the attack occurred at home. Arterial blood samples were taken on admis- sion to hospital (in 26) or within several hours of admission (in four)-whenever respiratory failure was first suspected clinically. In five children the attack occurred during a hospital stay-for parentectomy in three and steroid withdrawal in two. In all cases, patients were treated with xanthine compounds (orally or intravenously, or both) and $\beta$ stimulants (orally only, if possible) before sampling.

Heparinised arterial blood was drawn from the radial artery before oxygen and alkali were given. All blood samples were analysed for arterial oxygen tension $\left(\mathrm{PaO}_{2}\right)$, arterial carbon dioxide tension $\left(\mathrm{PaCO}_{2}\right)$, and arterial $\mathrm{pH}$ immediately after sampling. An ABL2 Acid-base laboratory (Radiometer Corporation, Copenhagen) was used for analysis. The normogram of Siggaard-Andersen ${ }^{11}$ was used to evaluate the acid base status. The point of sampling was assumed to be a steady state, and the alveolar-air equation ${ }^{8}$ was used for further analysis.

The alveolar-arterial oxygen tension gradient $\left(\mathrm{A}-\mathrm{aDo}_{2}\right)$ was then calculated by subtraction.

$$
\mathrm{A}-\mathrm{aDo}_{2}=\mathrm{P}_{\mathrm{I}} \mathrm{O}_{2}-\frac{\mathrm{PaCO}_{2}}{\mathrm{R}}-\mathrm{PaO}_{2}
$$

where $\mathrm{P}_{1} \mathrm{O}_{2}=$ oxygen tension of inspired gas and $\mathbf{R}=$ respiratory quotient.

Because patients included in this study were breathing room air only at the time of sampling the $\mathrm{P}_{\mathrm{I}} \mathrm{O}_{2}$ was assumed to be $19.9 \mathrm{kPa}$. In this study, $\mathrm{R}$ is assumed to be $0 \cdot 85.12$ 
The $\mathrm{PaCO}_{2}$ is known to be a direct reflection of the adequacy of alveolar ventilation ${ }^{13}$ and we regarded a $\mathrm{PaCO}_{2}$ of more than $5.9 \mathrm{kPa}$ as an indicator of alveolar hypoventilation. ${ }^{14}$ Although the calculated $\mathrm{A}-\mathrm{aDo}_{2}$ has a limited value (as discussed above) it was regarded as an indicator of ventilation/perfusion inequality because more accurate measurement techniques were impossible to perform during most critical asthmatic episodes.

Statistical analysis was performed using Student's $t$ test and the Person correlation coefficient was calculated.

\section{Results}

Arterial oxygen tension and arterial carbon dioxide tension. In 33 measurements out of 35 , the $\mathrm{PaO}_{2}$ was less than $9.3 \mathrm{kPa}$, and in 19 it was less than $7.9 \mathrm{kPa}$. Hypercapnia $\left(\mathrm{PaCO}_{2}\right.$ more than $\left.5.9 \mathrm{kPa}\right)$ was seen on 13 occasions. The $\mathrm{PaO}_{2}$ was mean (SD) $7 \cdot 7(1 \cdot 1) \mathrm{kPa}$ and the $\mathrm{PaCO}_{2}$ was $5.7(1.2) \mathrm{kPa}$. One patient required mechanical ventilation during three attacks of asthma. All patients recovered.

Arterial pH and the logarithmic arterial carbon dioxide tension. These are shown in Fig. 1. The normogram of Siggaard-Andersen was employed. In 16 episodes the $\mathrm{PaO}_{2}$ was above $7.9 \mathrm{kPa}$. Ten $(63 \%)$ patients did not have acid base disorders, two had a mild metabolic acidosis, and two had a

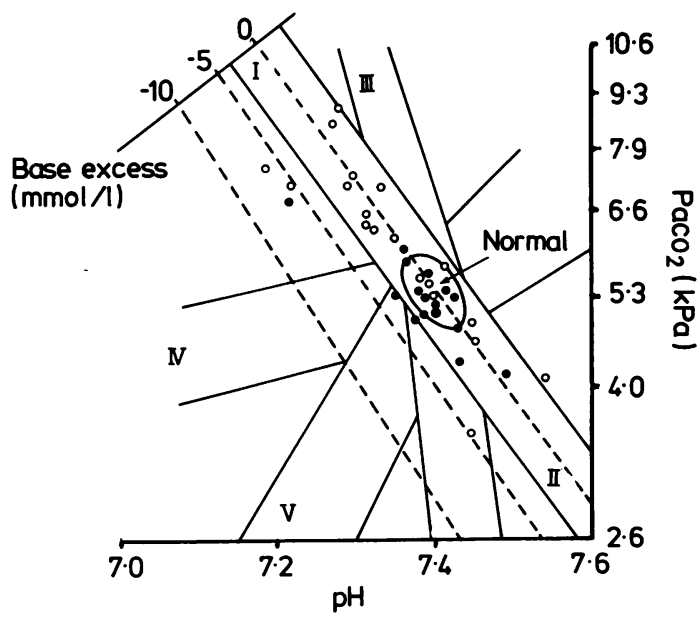

Fig. 1 Log $\mathrm{PacO}_{2}$ in relation to $\mathrm{pH}$ showing acid base status. ${ }^{\prime}$

\footnotetext{
Open circles $=\mathrm{PaO}_{2} \leqslant 7.9 \mathrm{kPa}$; closed circles $=\mathrm{PaO}_{2}>7.9 \mathrm{kPa}$.

$\mathrm{I}=$ acute respiratory acidosis.

II = acute respiratory alkalosis.

III = chronic respiratory acidosis

IV = acute base deficit.

$\mathrm{V}=$ chronic base deficit.
}

respiratory alkalosis. Interestingly, two in this group had a respiratory acidosis, one of whom had a combined respiratory and metabolic acidosis (details are shown in Table 1).

In 19 episodes the $\mathrm{PaO}_{2}$ was below $7.9 \mathrm{kPa}$ and acid base disorders were more severe and variable. Only four $(21 \%)$ patients did not experience acid base disorders. Eleven had a respiratory acidosis, two of whom had a combined respiratory and metabolic acidosis. These two required mechanical ventilation. Four patients had a respiratory alkalosis, associated with metabolic acidosis in one. Metabolic acidosis was seen in a total of six $(17 \%)$ patients.

Pathophysiological analysis of the cause of the hypoxaemia. The relation between $\mathrm{PaO}_{2}$ and $\mathrm{PaCO}_{2}$ was used for further analysis and the $\mathrm{A}-\mathrm{aDO}_{2}$ was calculated by the equation given above (Fig. 2). As

Table 1 Blood gas measurements in two asthmatic patients with hypercapnia $\left(\mathrm{PaCO}_{2} \geqslant 5.9 \mathrm{kPa}\right)$ and $\mathrm{PaO}_{2}>9.3 \mathrm{kPa}$

\begin{tabular}{lllllll}
\hline $\begin{array}{l}\text { Case } \\
\text { no }\end{array}$ & Sex & $\begin{array}{l}\text { Age } \\
(y r s)\end{array}$ & $\begin{array}{l}\mathrm{PaCO}_{2} \\
(\mathrm{kPa})\end{array}$ & $\begin{array}{l}\mathrm{PaO}_{2} \\
(\mathrm{kPa})\end{array}$ & $\begin{array}{l}\mathrm{A-aDo} \\
(\mathrm{kPa})\end{array}$ & $p H$ \\
\hline 1 & $\mathrm{M}$ & 11 & 6.8 & 9.6 & 2.3 & 7.219 \\
2 & $\mathrm{~F}$ & 10 & 5.9 & 9.6 & 3.2 & 7.356 \\
\hline
\end{tabular}

Conversion-SI to traditional units: $1 \mathrm{kPa} \approx 7.5 \mathrm{mmHg}$.

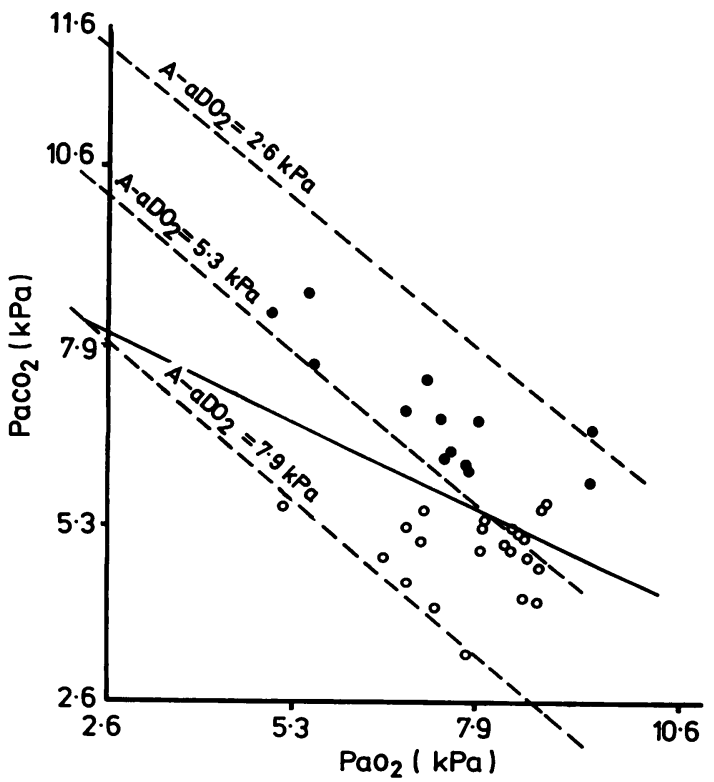

Fig. 2 Correlation between $\mathrm{PaCO}_{2}$ and $\mathrm{PaO}_{2}$.

The solid line indicates the regression $\left(\mathrm{PacO}_{2}=-0.49 \mathrm{PaO}_{2}+9.5, \mathrm{r}=-0.46\right)$ Open circles $=\mathrm{PaCO}_{2}<5.9 \mathrm{kPa}$; closed circles $=\mathrm{PaCO}_{2} \geqslant 5.9 \mathrm{kPa}$. 
expected there was a significant inverse correlation between $\mathrm{PaO}_{2}$ and the $\mathrm{PaCO}_{2}$, but the correlation coefficient was smaller $(r=-0.46)$ than previously reported $\left(\mathrm{r}=-0.75\right.$, Simpson $e t a \Gamma^{5}$ and $\mathrm{r}=-0.61$, Downes $e t a l) .{ }^{6}$ The differences in patient selection may be responsible for this discrepancy, because our series included the most severely affected patients only.

In Table 2, episodes associated with (type II) and without (type I) hypercapnia $\left(\mathrm{PaCO}_{2}\right.$ more or less than $5.9 \mathrm{kPa}$ ) are analysed separately. In episodes without alveolar hypoventilation (without hypercapnia), the $\mathrm{PaO}_{2}$ was significantly inversely correlated with the $\mathrm{A}-\mathrm{aDo}_{2}$ but not the $\mathrm{PaCO}_{2}$, but in patients who experienced alveolar hypoventilation, however, the $\mathrm{PaO}_{2}$ was significantly inversely correlated with the $\mathrm{PaCO}_{2}$ but correlated only roughly with the $\mathrm{A}-\mathrm{aDo}_{2}$.

Physiological causes of the severe hypoxaemia. In 19 episodes, the $\mathrm{PaO}_{2}$ was below $7.9 \mathrm{kPa}-11$ were accompanied by the hypercapnia, and eight were not. As shown in Table 3, patients with severe hypoxaemia were divided into two subgroups: (1) type I, severe hypoxaemia without hypercapnia (hypoxaemic respiratory failure); and (2) type II, severe hypoxaemia with hypercapnia (hypoventilatory failure). The $\mathrm{PaO}_{2}$ was comparable in both groups but the $\mathrm{PaCO}_{2}$ was significantly higher, the arterial $\mathrm{pH}$ significantly lower in the type II group,

Table 2 Correlations between $\mathrm{PaO}_{2}$ and $\mathrm{PaCO}_{2} / \mathrm{A}-\mathrm{aDo}{ }_{2}$ during episodes of hypoxaemia with (type II) and without (type I) hypercapnia

\begin{tabular}{|c|c|c|}
\hline Correlation & $\begin{array}{l}\text { Type I }(n=22) \\
\left(\mathrm{PaCO}_{2}<5.9 \mathrm{kPa}\right)\end{array}$ & $\begin{array}{l}\text { Type II }(n=13) \\
\left(\mathrm{PaCO}_{2} \geqslant 5.9 \mathrm{kPa}\right)\end{array}$ \\
\hline $\begin{array}{l}\mathrm{PaCO}_{2} \\
\mathrm{~A}-\mathrm{aDO}_{2}\end{array}$ & $\begin{array}{l}r=-0.07 \\
(N S) \\
r=-0.78 \\
(P<0.001)\end{array}$ & $\begin{array}{l}r=-0.81 \\
(P<0.005) \\
r=-0.64 \\
(P<0.05)\end{array}$ \\
\hline
\end{tabular}

NS=not significant.

Table 3 Blood gas measurements and mean age in 19 asthmatic children with severe hypoxaemia $\left(\mathrm{PaO}_{2} \leqslant 7.9\right.$ kPa) with (type II) and without (type I) hypercapnia

\begin{tabular}{|c|c|c|}
\hline & $\begin{array}{l}\text { Type I } \\
(n=8)\end{array}$ & $\begin{array}{l}\text { Type II } \\
(n=11)\end{array}$ \\
\hline \multicolumn{3}{|l|}{ Age (yrs) } \\
\hline Mean (SD) & $11 \cdot 1(3 \cdot 3)$ & $11 \cdot 1(3 \cdot 2)$ \\
\hline $\mathrm{PaCO}_{2}(\mathrm{kPa})$ & $4.8(0 \cdot 7)^{*}$ & $7 \cdot 1(0 \cdot 8)^{*}$ \\
\hline $\mathrm{PaO}_{2}$ & $6.9(0.7)$ & $6.9(1.0)$ \\
\hline $\mathrm{A}-\mathrm{aDO}_{2}$ & $7 \cdot 4(0.7)^{*}$ & $4.6(0 \cdot 7)^{*}$ \\
\hline pH & $7.436(0.047)^{*}$ & $7.294(0.044)^{*}$ \\
\hline
\end{tabular}

and the $\mathrm{A}-\mathrm{aDo}_{2}$ was significantly higher in the type $\mathrm{I}$ patients.

\section{Discussion}

The progression of the arterial blood gas disorders that occurs in acute severe asthma has been described as a uniform process. In the early stage, the usual manifestations are hypocapnia due to hyperventilation and hypoxaemia due to ventilation/ perfusion inequality (mismatch). The hypocapnia is accompanied by a raised $\mathrm{pH}$, respiratory alkalaemia. ${ }^{15}$ With progression, the work of breathing exceeds the capacity of the respiratory 'pump', and alveolar hypoventilation develops, resulting in retention of $\mathrm{CO}_{2}$ and ultimately acidaemia. ${ }^{115}$ Ventilation/perfusion inequality (increase in $\mathrm{A}-\mathrm{aDo}_{2}$ ) is considered to result in hypercapnia only late in the disease.

Although the finding of an acute respiratory acidosis is considered to be a danger signal, ${ }^{16}$ no reliable guides to the $\mathrm{PaCO}_{2}$ value or rapid clinical deterioration are known, ${ }^{5} 16$ and the value of the widening $\mathrm{A}-\mathrm{aDo}_{2}$ as a predictor of forthcoming hypercapnia and rapid clinical deterioration has not been fully investigated. Thus, some questions remain. Firstly, whether the pattern of progression to hypercapnia and severe hypoxia of asthmatic patients is individual or uniform, and secondly, whether or not the increased $\mathrm{A}-\mathrm{aDo}_{2}$ value is a predictor of the forthcoming hypercapnia.

In the present study, two different patterns of progression of blood gas derangement have emerged: hypoxaemic respiratory failure and hypoventilatory failure. In the former (type I), the hypoxaemia is caused by a wide and increasing (6.6 $\mathrm{kPa}$ or more) $\mathrm{A}-\mathrm{aDO}_{2}$ value without alveolar hypoventilation, and in the latter (type II), the hypoxaemia is caused by a relatively mild but increasing $(5.3 \mathrm{kPa}$ or less) $\mathrm{A}-\mathrm{aDO}_{2}$, and coexisting alveolar hypoventilation. It was observed that hypoventilation could occur even in the most mildly hypoxaemic patients, with a small $\mathrm{A}-\mathrm{aDo}_{2}$ value (Table 1 ).

The above observations suggest that the pattern of progression of blood gas disorders in acute, severe asthma is not uniform. All patients may develop hypoventilation ultimately, but the point at which this occurs may be different. Some patients may tolerate a considerably large ventilation/ perfusion inequality, and others may not. Thus, the value of $\mathrm{A}-\mathrm{aDO}_{2}$ is not a predictor of forthcoming hypercapnia: furthermore not only patients with hypercapnia (type II) but those with the normo- or hypocapnia (type I) may suffer a critically severe hypoxaemia. In the present study, no episodes associated with type I failure required mechanical 
ventilation, but the severity of the hypoxaemia was not different between these two groups (Table 3).

In conclusion, the classification of acute respiratory failure into hypoxaemic respiratory failure (type I) and hypoventilatory failure (type II), is considered to be useful in understanding the pathophysiology of acute, severe asthma in childhood. Although hypoventilatory failure is known to be relatively rare in adults, ${ }^{4} 12$ it seems more common in children. ${ }^{7}$ In these two groups with respiratory failure in acute severe asthma, the difference in airways resistance, the responsiveness to different mediators, ${ }^{17}$ the ventilatory control (hypoxic and hypercapnic response), ${ }^{18-20}$ and many other pathophysiologic factors should be studied further.

\section{Conclusion}

Two different patterns in the progression of arterial blood gas disorders in children with acute, severe asthma have emerged. In type I, a large and widening $\mathrm{A}-\mathrm{aDo}_{2}$ was considered to be the sole mechanism behind the severe hypoxaemia, and in type II, a limited but widening $\mathrm{A}-\mathrm{aDo}_{2}$ and coexisting alveolar hypoventilation were deemed to be the causative mechanisms. I speculate that type I failure is not always merely the first stage of the type II disorder. Even in type I failure, critically severe hypoxaemia was not uncommon. Some patients may tolerate considerably large ventilation/perfusion inequality, and others may not. The pathophysiological basis of the difference between these two groups needs to be investigated further.

\section{References}

${ }^{1}$ Petty TL. Status asthmaticus in adults. In: Middleton E Jr, Reed CE, Ellis EF, eds. Allergy-principle and practice. Saint Louis: CV Mosby Co, 1978:771-9.

2 Anonymous. Hypercapnia in bronchial asthma [Editorial]. Lancet 1973;i:140-1.

${ }^{3}$ McFadden ER Jr, Lyones HA. Arterial-blood gas tension in asthma. $N$ Engl $J$ Med 1968;278:1027-32.
${ }^{4}$ Nowak RM, Tomlanovich MC, Sarkar DD, et al. Arterial blood gases and pulmonary function testing in acute bronchial asthma. JAMA 1983;249:2043-6.

${ }^{5}$ Simpson H, Forfar JO, Grubb DJ. Arterial blood gas tensions and $\mathrm{pH}$ in acute severe asthma in childhood. $\mathrm{Br}$ Med $\mathrm{J}$ 1968 ;iii: $460-4$.

${ }^{6}$ Downes JJ, Wood DW, Striker TW, et al. Arterial blood gas and acid-base disorders in infants and children with status asthmaticus. Pediatrics 1968;42:238-49.

${ }^{7}$ McKenzie SA, Edmunds AT, Godfrey S. Status asthmaticus in children-a one-year study. Arch Dis Child 1979;54:581-6.

${ }^{8}$ Martin L. Respiratory failure. Med Clin North Am 1977; 61:1369-96.

${ }^{9}$ Balk R, Bone RC. Classification of acute respiratory failure. Med Clin North Am 1983;67:551-6.

11 D'Alonzo GE, Dantzker DR. Respiratory failure, mechanisms of abnormal gas exchange, and oxygen delivery. Med Clin North Am 1983;67:557-71.

1 Siggaard-Andersen O. An acid-base chart for arterial blood with normal and pathophysiological reference areas. Scand J Clin Lab Invest 1971;27:239-45.

12 Toyama T. A clinical study of respiratory failure-with special reference to arterial blood gas. Osakashi Igakkai Zasshi 1978;27:21-43. (in Japanese).

13 Shapiro BA, Harrison RA, Trout RN. Clinical cvaluation of the pulmonary system. Clinical application of respiratory care. 2nd ed. Chicago: Year Book Medical Publishers, 1979:98-114.

14 Rebuck AS, Read J. Assessment and management of severe asthma. Am J Med 1971;51:788-98.

15 Rebuck AS, Braude MB, Chapman KR. Evaluation of the severity of the acute asthmatic attack. Chest 1982;82:28S-9S.

16 Weiss EB, Faling LJ. Clinical significance of $\mathrm{PaCO}_{2}$ during status asthma-the cross over point. Ann Allergy 1968;26: 545-51.

17 Bhagat RG, Grunstein MM. Comparison of responsiveness to methacholine, histamine, and excrcise in subgroups of asthmatic children. Am Rev Respir Dis 1984;129:221-4.

${ }_{18}$ Morrill CG, Dickey DW, Cropp GJA. Ventilatory response and drive of asthmatic children to alveolar hypoxia. Pediatr Res 1981;15:1520-4.

${ }^{19}$ Bradley CA, Fleetham JA, Anthonisen NR. Ventilatory control in paticnts with hypoxia due to obstructive lung discase. Am Rev Respir Dis 1979;120:21-30.

20) Hutchson AA, Olinsky A. Hypoxic and hypercapnic response in asthmatic subjects with previous respiratory failure. Thorax 1981:36:759-63.

Correspondence to Dr T Hori, Department of Pediatric Nephrology, Kidney Center, Tokyo Women's Medical College, Ichigayakawada-cho, Shinjuku-ku, Tokyo 162, Japan.

Received 21 February 1985 